\title{
FORMATION OF TEACHERS' DIGITAL COMPETENCE: DOMESTIC CHALLENGES AND FOREIGN EXPERIENCE
}

\author{
TETYANA BLYZNYUK
}

\begin{abstract}
Education system in Ukraine is undergoing large-scale reforms including modernization on different school levels and higher educational institutions. Students' world view is laid out at school, that is why teachers must be ready to promote new content of education. According to the Concept "New School of Ukraine" among the key competencies of a student are the ability of intercultural communication in social and cultural contexts, digital competence, awareness of national identity as the basis of open-mindedness and respect for the diversity of cultural expression of others, and more. With this paper the author intends to initiate modifying demanded competencies and skills for contemporary primary school teachers based on cross-cultural experience. The article explains the necessity of forming a digital competence as a separate component of the professional skills of the modern teacher and shows its influence on the development of the personality of the modern student. Much attention is drawn to the domestic challenges in the implementation of digital devices in classrooms. Some foreign experience is analyzed in this research.
\end{abstract}

Keywords: digital competence, teachers, higher educational institutions, schools, students, active learning/teaching.

\section{INTRODUCTION}

Nowadays all of us live in the digital world and often face the question if the presence of gadgets in our children's hands can detract their attention from study? Today all experts speak about importance of formation digital literacy from the initial level. Digital literacy (DL), a term that emerged with the explosion of digital information and multimedia technology, refers to basic competence in using digital technology. Nowadays schoolers are so much accustomed to digital technologies through various gadgets that they actually think it is their natural environment. However, with this chaotic and unskillful use children themselves, their parents, and teachers face many issues related to technologies. Among the emerged problems scientists single out Internet addiction and bullying, illegal downloading, and other coherent problems. It is obvious that children need to develop a new kind of knowledge today which will enable them to function effectively in the digital society. This knowledge is recognised by Eshet-Alkalai and Amichal-Hamburger (2004) as digital literacy (DL) or digital competence (DC) [1]. 
DC is a comparatively new concept that shows the demand of user's ability in the digital environment. Its definition has thus emerged with the development of innovative technologies throughout the world. For the recent years, different terms have been used to describe the skills and knowledge of using digital technologies, such as skills in information communication technologies (ICT), technology skills, information technology skills, 21st century skills, information literacy, digital literacy, and digital skills. Most of these terms are often used as synonyms by scholars; e.g. digital competence and digital literacy. Therefore, different researches of the concept have their own understanding of this term and suggest their definitions.

A number of Ukrainian scholars have explained the content key competencies during implementation of information and communication technologies. Professor N. Morze and I. Vorotnykova introduced the model of ICT-competence of the teachers. Besides, in her researches she contributed to deeper understanding of ICT role in education, ICT learning, organizationalmethodological activities, and specified the instruments of teacher's ICT competence measurement by the three levels, according to UNESCO international standards (technological literacy, deepening of knowledge, creation of knowledge) [4]. M. Zhaldak, Y. Ramsky generalized specific approaches to explanation different titles of competencies related to digital wave in pedagogical literature: information, information and technology, ICT competencies, etc. [2].

DC refers to the confident and conscious usage of the whole range of digital technologies for information, communication and basic problem-solving in all aspects of life, including education. There is a vivid discussion on the problem of inclusion of digital tools in schools. According to Common Digital Competence Framework for Teachers "Digital competence is one of the 8 key competences that every young person should have developed by the end of Compulsory Education to equip them for adult life and permanent lifelong learning... Digital competence not only provides the ability to make use of the wealth of new possibilities associated with digital technologies and the challenges they imply, but it has also become increasingly necessary to participate meaningfully in the new knowledge society and in the economy of the twenty-first century" [8].

\section{ANALYSIS AND DiscUSSION}

Teaching profession constantly faces rapidly changing requirements, which demand a fresh, wider and more complicated set of competencies than before. "Those who are responsible for teaching students of the new millennium have to be able to guide them in their educational journey through the new media... Teachers need a clear political message in this regard: public recognition of what they are expected to do to develop these competences as a priority in their areas or fields. This public recognition will in turn require priority attention in teacher training systems and the recognition of teachers' professional development. The need to ensure high quality teaching has become one of the priorities of the "European Strategic Framework for Education and Training" (ET 2020). [8]. Alongside with remarkable attention of European Commission to the development of digital competence for teachers Ukrainian governmental officials simultaneously stress on teachers' readiness for innovation, new standards and learning outcomes, and emphasize the importance of forming key competencies in schoolchildren for lifelong learning. Among ten major competencies of the Ukrainian school are the following: communication in national and foreign languages, competencies in Science and Technology, ICT and digital competencies, etc. According to the document, "these key competencies and crossdisciplinary abilities create an infrastructure that provides the grounds for successful self-fulfillment of the pupil as a personality, citizen and professional" [7, p. 12].

Thus, schools have to remain open to the world and to use new innovative tools and methods to survive. We cannot go on keeping schools aside of obvious changes: every day students bring the changing world inside their classrooms and much depends on the teacher's attitude to innovations.

The universal application of digital devices, in particular, requires from educators themselves to develop their own digital competence. Our research shows that present primary and secondary school teachers have insufficient digital skills. Most of the interviewed self-assessed themselves as proficient 
users only in online communication, they have some abilities in information processing, but lack knowledge and skills relating to the educational content creation (for example, texts, tables, images and illustrations, audio files, videos and tutorials), safety and educational problem-solving (See Fig. 1).

With the aim of forming some elements of teachers' and students' digital competence, training "Methods of Inquiry based learning of STEM subjects: inquiry learning space and tools" was held on the base of Vasyl Stefanyk Precarpathian National University (PNU) by the coach Olga Dziabenko, a researcher, certified trainer who regularly speaks at conferences and workshops, runs numerous projects at the University of Deusto in Bilbao, Spain. Within November 8-9, 2017 students and the teaching staff of the PNU got excellent opportunities to get acquainted with Inquiry Based Learning, instrument tools of Go-Lab ecosystem: online laboratories, inquiry learning spaces (ILS), existing apps and active learning tutorials from the experienced trainer. Besides, the participants of the training practiced in creating own educational content - inquiry learning spaces for primary and secondary school pupils in STEM subjects.

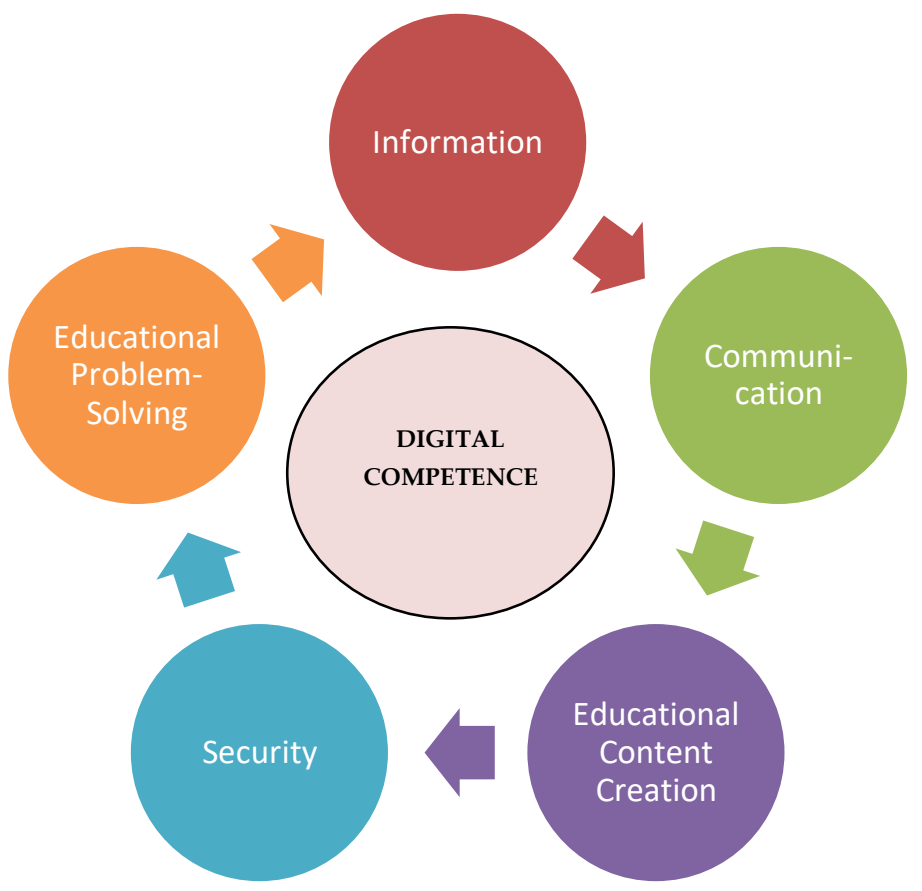

Fig. 1. Digital Competence Framework.

For the present time the outcomes of the training are five successfully published ILS in the Ukrainian language (Olena Budnyk, Sergiy Mikitsey, Diana Gladeniuk, Olga Boichuk, Tetyana Blyznyuk) and more are still to come out (http://www.golabz.eu/spaces). The ILS-s are ready for use by creative and innovative teachers who will foster active learning methods in schools and develop pupils' digital skills. Go-Lab Project (2012-2016) - Global Online Science Labs for inquiry learning at schools makes available online research laboratories for widespread use in the field of education. Its technological basis is a portal that provides the opportunity to conduct scientific independent experiments in the virtual laboratory, while the teacher can complete it with some demonstrations of video files and control the students' activities in the classroom and share the best practices within the teaching community.

Using active learning with all innovative instruments of learning/teaching does not necessarily mean complete ignoring the traditional lecture format, but it does take class time. Lecturers or teachers who use active learning methods make frequent pauses during the period in order to give students some time to work out the information they are provided with. Teachers may ask students to respond to several questions, to summarize important concepts orally or in writing, or compare notes with a partner. Breaking students into groups or other strategies such as individual 
writing or paired activities are quite possible and lead to good results as well. There are many teaching strategies that can be successfully used to actively engage students in the learning process and develop their competencies, including group discussions, problem solving, case studies, role plays, journal writing, and structured learning groups, etc. There are many benefits to using such activities, as they aim to improve critical thinking skills, increase retention and transfer new information, increase motivation, and improve interpersonal skills and other competencies. Students and their learning needs must be at the center of active learning both at schools and higher educational institutions. And perhaps we should give less attention to those tests we got used to, but evaluate students or teachers according three $\mathrm{C}$ approach: communication, creativity, critical thinking and collaboration?

Esther Wojcicki, an American educator and researcher on blended learning in school, shares her ideas on how to apply active learning and digital tools in the classroom. In her view, it is good to give students $20 \%$ of the week work on projects, for example, and $80 \%$ for other activities. It will make the learning process relevant. Of course, it might be that students don't like it at first. The teacher can see a chaos as students may not understand what they actually do. But at the end of the month the teacher can be surprised at how much they have learned.

However, as have been mentioned before much depends upon teachers' attitude to innovations. According to another researcher Luis Fernandes, a Portuguese, head teacher with a passion for education and technology, to be successful, any innovative project should include three key steps: planning, experimentation and dissemination. To plan the incorporation of digital tools is a challenge with many variables and it is therefore necessary to experiment, to make mistakes: to learn. In his opinion, such planning requires understanding of human resources available before implementing any project. In his view, teachers may be divided into three digital development stages according to the way they respond to new challenges:

A - This could be useful, I'll give it a try!

B - I should look into this, but it's not important now!

C - I don't have the time to look into it, and in a year's time things will have moved on!

In this way, with the smaller, more motivated group $\mathrm{A}$, it is possible to forge ahead and experiment without fearing failure, and gather very valuable data to disseminate the project. It is important to conduct some reflection on student-reported improvements in different educational aspects. The next step, dissemination, will cover the group B teachers, with the support of the early experimenters. This group of "pioneers" can motivate the others more easily giving examples and assisting the new group. The group $C$ teachers who are more reluctant and passive may or may not join the ongoing movement, since the students who are already participating in the project will now help its implementation, together with the other teachers [3].

The innovator also suggests several ideas of implementing digital tools in schools in a wise way. First of all, he finds it essential that teachers feel the motivation to do it. They have to understand that the methodologies they still use are no longer sufficient, and that more efficient and student-centred methodologies, such as the flipped classroom, project-based learning, etc., are a suitable response (choice of new methodologies). Secondly, many contents available on the market are expensive, or free but of poor quality. Therefore, teachers have to create their own educational contents, adapt them to their classroom situations and work out multimedia presentations that can meet students' specific demands (choice of new content). Thirdly, the best device is the one which can be used for all academic tasks, i.e. with a keyboard, a tactile screen, and if possible a digital pen. These features will cover most activities (choice of innovative tools and devices). And finally, from common well-known experience, the best way to bring innovation to schools is by "contagion". A teacher who experimented, failed, and learned, it is the best example for the rest. A real example always works better (contagion effect) [3].

Definitely, many Ukrainian schools have the problem not only with teachers training and readiness for using digital tools in classrooms but also with poor material support or simply complete absence of modern digital devices at schools. 
As the survey of numerous Ukrainian researches shows that the rate of students who have teachers who often create digital resources and participate actively in the educational websites or in virtual learning environments and social media of professional collaboration is very low. At the same time, we can admit that more than $90 \%$ of students of the last years of primary education already own and use their mobile devices and computers connected to the Internet to perform some educational tasks and spend their leisure time or communicate with their friends in social settings. Over $75 \%$ of these students have teachers who never or almost never communicate digitally with their families, assess the use of ICT by students, assess digital resources or give homework to their students online, etc.

The project of the European Union ERAZMUS + CA2 Higher Education Opportunity Project: Modernizing Educational Higher Education Using Innovative Teaching Tools (MoPED) - No. 586098ERP-1-UA-EPPKA2-CBHE-JP was launched at the PNU in 2017 as one step in this direction. Experts believe, it will have a positive impact on the quality of higher pedagogical education and will improve the digital and didactic competences of future school teachers. The project is initiated to answer many challenges by contributing to the modernization of UA pedagogical curricular by creating and introducing new educational courses, arranging modern innovative classrooms throughout certain Ukrainian higher educational institutions. It is supposed to enhance the professional level of pre-/inservice teachers by incorporating new subjects of top-notch ICT teaching tools and inquiry methods.

\section{ConClusions}

From the above mentioned information we attempt to conclude that in Ukraine education is only taking its first steps to become a knowledge industry. Firstly, it requires all students, university and school teachers, local and state education officials to act as a professional team, who have the desire and power to act, have all necessary information to make complex decisions, and get effective support to help meet numerous challenges. We consider it the major factor for the new digital technologies implementation in the classroom. Secondly, regular teacher trainings in digital competence are extremely essential. So that to be able to determine what kind of support is necessary for such teacher trainings in digital competence, in both initial training and continuing professional development, it is urgent to refer to a common framework with enough recognition; which specifies measurable indicators for each area of digital competence (information, communication, content creation, security and problem-solving). Furthermore these measurable indicators have to be diversified suggestions of standards, which differentiates between requirements for students, school and higher educational institutions teachers and more.

In our research the main aspect was drawing attention to improving future teachers' digital competence. As only lecturers at higher educational institutions can train such teachers who will eagerly use their digital knowledge at schools and equip their students with new skills to be able to learn throughout life, think critically, achieve goals, communicate cross-culturally and be competitive in the labour market.

Kids love technology. If teachers give them opportunity to explore using technology, their excitement will grow. If they had opportunity to use a computer, phone, tablet or something else as the basis for exploring, we would be satisfied with the results we see.

\section{REFERENCES}

[1] Eshet-Alkalai Y., Amichal-Hamburger Y. Experiments in Digital Literacy. CyberPsychology E Behavior, 7 (4) (2004), 421-429. Available at: https://www.openu.ac.il/personal_sites/download/eshet\&Amichai 2004.pdf. 
[2] Zhaldak M. Some methodological aspects of teaching science in school and Pedagogical University. Scientific notes Ternopil National University. B. Hnatyuk. Series: Pedagogy, 6 (2005), 17-24. (in Ukrainian)

[3] Fernandes L. How to have an effective whole-school approach to digital tools in education? School Education Gateway, (2016). Available at: https://www.schooleducationgateway.eu/en/pub/ viewpoints/experts/how_to_address_the_challenges_.htm.

[4] Morze N., Vorotnykova I. The Model of ICT Competence of teachers. Science Rise. Pedagogical Education, 10 (2016), 4-9. Available at: http://nbuv.gov.ua/UJRN/texcped_2016_10_3. (in Ukrainian)

[5] Morze N., Kuzminska O., Protsenko G. Public Information Environment of a Modern University. CEUR Workshop Proceedings, June 19-22 (2013), 264-272. Available at: http://ceur-ws.org/Vol-1000/ICTERI2013-p-264-272.pdf. (in Ukrainian)

[6] Morse, N., Kocharian, A. B. Information and communication competence of teaching staff of the university. Informacijni tehnologii' $i$ zasoby navchannja, 43 (5) (2014), 27-39. Avaialble at: http://elibrary.kubg.edu.ua/6198. (in Ukrainian)

[7] New School - Ministry of Education and Science of Ukraine. Available at: https://mon.gov.ua/ua/news/ usi-novivni-novini-2016-08-23-mon-zaklikae-osvityan-ta-gromadskist.

[8] Common Digital Competence Framework for Teachers 2017 INTEF. Available at: http:// aprende.educalab.es/wp-content/uploads/2017/03/marco_competencia_digital_docente_2017_ENG.pdf.

[9] Recommendation of the European Union and of the Council of 18 December 2006 on key competences for lifelong learning. Official Journal of the European Union, (2006). Available at: http://eurlex.europa.eu/LexUriServ/LexUriServ.do?uri=OJ:L:2006:394:0010:0018:en:PDF.

[10] Europe's Digital Competitiveness Report. Luxembourg. European Commission, (2010). Available at: http://ec.europa.eu/information_society/digital-agenda/documents/.

[11] Rethinking Education. European Commission, (2012). Available at: http://www.mecd.gob.es/redieeurydice/Prioridades-Europeas/Rethinking.html.

[12] Ferrari A. DIGCOMP: A Framework for Developing and Understanding Digital Competence in Europe. European Commission, (2013). Available at: http://ipts.jrc.ec.europa.eu/publications/pub.cfm?id=6359.

Address: Tetyana Blyznyuk, Vasyl Stefanyk Precarpathian National University, 57, Shevchenko Str., IvanoFrankivsk, 76018, Ukraine.

E-mail: blyztan@yahoo.com.

Received: 14.11.2017; revised: 05.03.2018.

Тетяна Близнюк. Формування цифрової компетентності вчителів: українські реалії та зарубіжний досвід. Журнал Прикарпатського університету імені Василя Стефаника, 5 (1) (2018), 40-46.

У статті нагодошено на тому, що система освіти в Україні переживає сьогодні масштабні реформи, вкдючаючи модернізацію на різних рівнях освіти шкільних та вищих навчальних закладів. Світогляд учня закладається саме в школі, тому вчителі повинні бути готові створювати i впроваджувати новий зміст освіти. Відповідно до Концепції "Нова школа України" серед кдючових компетентностей учня є здатність спілкуватися державною та іноземними мовами, інформаційноцифрова компетентність, компетентності в природничих науках і технологіях, усвідомлення національної ідентичності як основи відкритості та поваги до різноманітності культурних. Цим дослідженням автор має намір ініціювати модифікацію зазначених компетентностей та навичок для сучасних учителів початкової школи на основі міжкультурного досвіду. У статті пояснюється необхідність формування цифрової компетентності як окремого компоненту професійних навичок сучасного педагога та показано іiі вплив на розвиток особистості сучасного учня. Значна увага приділяється внутрішнім проблемам у контексті використання цифрових пристроїв в класах. У цьому дослідженні автор аналізує певний зарубіжний досвід. 
Ключові слова: цифрова компетентність, учителі, вищі навчальні заклади, школи, студенти/учні, активне навчання / викладання.

\section{îำPED}

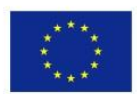

Co-funded by the Erasmus+ Programme of the European Union

«The article has been prepared in the framework of the Erasmus+ project "MoPED - Modernization of Pedagogical Higher Education by Innovative Teaching Instruments", No. 586098-EPP-1-2017-1-UA-EPPKA2CBHE-JP. This project has been funded with support from the European Commission. This publication reflects the views only of the author, and the Commission cannot be held responsible for any use which may be made of the information contained therein». 